\title{
TENDENSER I NYERE MARXISTISK RETSTEORI
}

\author{
Torben Wanscher
}

\section{Disposition}

I. Problemstilling og teoretisk udgangspunkt.

II. Den videnskabelige materialisme.

Tre teoretiske grundproblemer:

1. Retten som overbygning.

2. Retten som historisk fænomen.

3. Retten som klasseret.

III. »Kritisk « retsteori.

A. »Kritik «-begrebet.

1. Erkendelse og interesse.

2. Frigørelse.

3. Retskritik.
a. Ideologikritik.
b. Indholdskritik.
c. Dogmatikkritik.

4. Praksis.

B. Materialisme-opfattelse.

De tre grundproblemer:

1. Retten som overbygning.

2. Retten som historisk fænomen.

3. Retten som klasseret.

IV. Strukturalistisk retsteori.

A. »Struktur« begrebet.

1. Den »teoretiske praksis« og »erkendelsesobjektet

2. Skitse over »struktur«-begrebets elementer
3. Form-analyse.

4. Den kapitalistiske "produktionsmåde «

5. Reproduktion og funktion.

6. Ideologien og retten.

B. Materialisme-opfattelse.

De tre grundproblemer:

1. Retten som overbygning.

2. Retten som historisk fænomen.

3. Retten som klasseret.

V. Materialistisk retsteori.

A. »Kritik af den politiske $\varnothing$ konomi $\ll$.

1. Produktion og ret.

2. Den almene retsform.

3. Kritik.

4. Ideologi og ret.

5. Overfladen og retten.

6. Rettens funktioner som kapitalaffirmative.

7. Fasespecifikke retsformer.

B. Materialistisk udledning.

De tre grundproblemer:

1. Retten som »overbygning $«$.

2. Rettens historiske betingethed.

3. Retten som klasseret.

VI. Konkret analyse.

Det arbejdsretlige system. 


\section{Problemstilling og teoretisk udgangspunkt.}

Hensigten med denne artikel er at give en fremstilling af tendenserne i de seneste års marxistisk retsteoretiske opfattelser i Vesteuropa især med henblik på de nordiske lande.

Det problem, der i denne forbindelse særlig trænger sig på, er en afklaring af forholdet mellem en »marxistisk retsteori « og en »kritisk retsvidenskab $\ll$. Hvad er de »Marxistiske « elementer, og hvad er det »kritiske« indhold, og hvordan er den indbyrdes forbindelse herimellem?

Når jeg i det følgende taler om »marxistisk « retsteori, så mener jeg hermed, at den pågældende opfattelse står i et positivt tilegnende forhold til Marx/Engels' skrifter (både i sit indhold og i sin selvforståelse). Men dermed er ikke sagt noget om min opfattelse af rigtigheden af denne Marxforståelse.

Hos Marx og Engels findes ikke en færdigudarbejdet teori for det retlige system, men udtalelser om retlige spørgsmål og ansatser til en teoretisk forståelse heraf går som en rød tråd gennem hele det Marx/Engelske værk. ${ }^{1}$ Der rejser sig på baggrund heraf store metodiske vanskeligheder for oparbejdelsen af en marxistisk retsteori, som opfatter sig selv som marxistisk i den forstand, at den tager sit udgangspunkt i Marx' og Engels' skrifter. Vil man kunne sammenstrikke en retsteori, hvis man samlede alle de forskellige udtalelser hos Marx og Engels om retten til en skøn.mosaik? Et sådant fors $\emptyset \mathrm{g}$ vil være både indholdsmæssigt utilfredsstillende og - først og fremmest - metodisk uantageligt: $d a$ objektet for Marx og Engels ikke specifikt er retssystemet, men den kapitalistiske samfundstotalitet (herunder også retssystemet) med hovedvægten på den kapitallogiske reproduktion, $d a$ de forskellige udtalelser står i en vidt forskellig kontekst, nogle i historiske skrifter, andre i politisk-aktuelle skrifter, andre som led i en abstrakt begrebsudvikling o.s.v., og $d a$ Marx' og Engels' skrifter også i sig selv må vurderes historisk både i forhold til nedskrivningstidspunktets historiske situation og sin egen indre udvikling.

Men dermed være ikke sagt, at de forskellige retsteoretiske ansatser hos Marx og Engels ikke kan bruges som element i en teoriudvikling for den borgerlige ret. Det skal blot ske med udgangspunkt i en erkendelse af den teoretiske status, som den pågældende udtalelse har inden for den marxske teori.

Netop på dette punkt er der store mangler iden marxistiske retsteoretiske tradition, som har taget udgangspunkt i forskellige (tilfældige) steder hos Marx og Engels - lige fra Marx' ungdomsskrifter til Engels' sene breve. ${ }^{2}$

1. Jfr. Torben Wanscher, »Materialistisk retsteori,« Politica nr. 1, 1974, p. 1 ff.

2. F.eks. har en enkelt sætning i Det kommunistiske Manifest via Lenin og Wyschinskij spillet en afgørende rolle for udviklingen af en normativ viljesteoretisk retsteori i de socialistiske lande. Jfr. N. Reich, »Marxistische Rechtstheorie«, Recht und Staat, Tübingen 1973, p. 15. Jfr. også nedenfor om Kritisk retsteori og om Strukturalistisk retsteori. 
Alt i alt er den marxistiske retsteoretiske litteratur relativt sparsom, både i forhold til borgerlig retsteori og i forhold til den samfundsvidenskabelige dechiffreringskraft, der indeholdes i den marxske teori - også for det retlige system.

Udviklingslinierne i den postmarxistiske retsteoris historie (som står i nøje sammenhæng med faserne i arbejderbevægelsens historie og dermed igen med kapitalens udviklingsfaser) er ikke emnet for denne opsats. Derimod vil jeg forsøge at fremstille de udslag, som de seneste års fors $\emptyset \mathrm{g}$ på en rekonstruktion af den marxske teori har haft på det retsteoretiske område. Den grundlæggende opfattelse bag disse teoriudviklingsintentioner er enigheden om den teoretiske utilstrækkelighed af de postmarxistiske teorier (og retsteorier). Denne opfattelse kommer tydeligt til udtryk i et par vigtige retsteoretiske ansatser fra $1967^{3}$-midt i 60-ernes videnskabsteoretiske opgør. Her sætter denne artikels emne selv sin tidsmassige granse.

Derfor behandles $i k$ ke i denne sammenhæng retsteorien i de nuværende socialistiske lande og ej heller andre »marxistisk-leninistiske « teorier, hvor marxismen betragtes som en »verdensanskuelse« med den »dialektiske materialisme« som universel erkendelsesteori og den »historiske materialisme« som universel samfundsteori. ${ }^{4}$

Det er min opfattelse, at det er teoretisk muligt - og politisk nødvendigt - at oparbejde en materialistisk retsteori på grundlag af den marxske teori forstået som en teori for kapitalismen (det borgerlige samfund), der igennem »kritikken af den politiske фkonomi afdækker det kapitalistiske samfunds grundlæggende konstituenter, genese og udviklingstendenser.

De seneste års tendenser inden for marxistisk retsteori vil kunne forstås overvejende som tre videnskabelige »skoler $«$ :

3. Begge er trykt i »Archives de Philosophie du Droit«, Tome XII: »Marx et le droit moderne«, Paris 1967, og oversat til tysk i Norbert Reich, (Hrsg.): »Marxistische und sozialistische Rechtstheorie«, Frankfurt/M. 1972. U. Cerroni: »Marxismus und Recht - Historisch-kritische Überlegungen«, p. 172 (citeret fra N. Reich): »For at sige det lige ud, er det endnu sådan, at en marxistisk retsteori først skal til at skrives. ... Det drejer som om at fastslå, om og på hvilken måde det er muligt inden for den af Marx udarbejdede metodologi at udarbejde en linie for forskningen og den historisk-kritiske rekonstruktion af retten, en linie som gennem sin kritiske værdi ligger nær den, som Marx selv vedrørende den politiske økonomi har fulgt i »Kapitalen«. (Egen oversættelse. Dette gælder også for alle nedenfor anvendte tyskecitater, som ikke er citeret efter offentliggjorte skandinaviske oversættelser). N. Poulantzas: »Om marxisme og retten«, København/Århus 1972,p.75: »Man kan ikke begynde at fremstille de generelle principper i en marxistisk unders $\varnothing$ gelse af retten uden først at gøre opmærksom på visse forvrængninger, som den marxistiske retsteori længe har gennemgået. Disse er iøvrigt ikke specielle for den marxistiske retsteori, men er en del af de generelle teoretiske strømninger i fejlagtig tolkning af Marx inden for den marxistiske tænknings historie.«

4. Se hertil »Marxistisch-leninistische allgemeine Theorie des Staates und des Rechts«, bd. 1-2, DDR, Berlin 1974. Bd. 1: »Grundlegende Institute und Begriffe« (original Moskva 1970). Bd. 2: Historische Typen des Staates und des Rechts« (original Moskva 1971). P.E. Nedbailo, « »Einführung in die allgemeine Theorie des Staates und des Rechts. « Berlin, Staatsverlag der DDR, 1972. Norbert Reich, »Sozialismus und Zivilrecht«, Frankfurt/M. 1972. 
1. En »kritisk« retsteori, der overvejende bygger videre på Frankfurterskolen og på Habermas' Marx-»rekonstruktion« (jfr. afsnit III).

2. En strukturalistisk retsteori, der viderefører Althussers strukturalistiske Marxinterpretation (jfr. afsnit IV).

3. En materialistisk retsteori, der fors $\emptyset$ ger at videreudvikle den marxske »kritik af den politiske $\phi k o n o m i \ll$ med henblik på en teoridannelse for den borgerlige ret (jfr. afsnit V).

\section{Den videnskabelige materialisme.}

\section{Tre teoretiske grundproblemer.}

Det er som sagt ikke min hensigt at forsøge at give en tolkning af den muligt rekonstruerbare retsteori hos Marx/Engels og ej heller udviklingen i den postmarxistiske retsteori. Men jeg vil dog her fremdrage de tre teorielementer hos Marx/Engels, som har haft den største betydning for marxistiske teoridannelser på rettens område. Disse vil derfor blive anvendt som tematiske tyngdepunkter i den følgende fremstilling.

Disse teorielementer må forstås i forbindelse med det videnskabsteoretiske udgangspunkt hos Marx: Den videnskabelige materialisme. Det vil nedenfor blive påvist, at de tre »skoler« har forskellige opfattelser af den videnskabelige materialisme, tildels i overensstemmelse med, at materialisme-opfattelsen hos Marx selv gennemløber en udvikling. ${ }^{5}$ Men det vil dog være teoretisk forsvarligt foreløbigt at karakterisere den videnskabelige materialisme derved, at man i den materielle produktion - d.v.s. i produktivkræfterne (produktionsmidlernes tekniske udviklingsstade) og i produktionsforholdene (fordelingen af ejendomsretten til produktionsmidlerne) - skal søge nøglen til den videnskabelige forståelse af samfundstotaliteten.

Materialismen skal forstås i modsætning til den i datidens videnskab herskende videnskabelige idealisme, som i »ideen« (Hegel), »folkeånden« (von Savigny) eller lignende metafysiske konstruktioner ser samfundsudviklingens drivkraft.

Det materialistiske udgangspunkt ved analysen af retten formuleres af Marx f.eks. således i en polemisk skarpt tilskåret form, hvor netop et idealistisk (illusionært, d.v.s. ideologisk,) udgangspunkt afvises: »Ud fra den juridiske illusions standpunkt betragter han ikke loven som produkt af de materielle produktionsforhold, men omvendt produktionsforholdene som produkt af loven $\ll^{6}$

5. Jfr. H.-J. Schanz, »Til rekonstruktionen af kritikken af den politiske $\varnothing$ konomis omfangslogiske status «, Århus 1973, p. 20 ff. Se også Marx. »Grundrids til kritikken af den politiske økonomi«, Modtryk/Kurasje, Århus 1974, bd. 1, hvor »Oversætternes forord «p. XV ff. indeholder en kortfattet oversigt over den marxske teoriudvikling.

6. Kapitalen, MEW 23, p. 643f. (Rhodos p. 868).) 


\section{Retten som overbygning.}

»Indbegrebet af disse produktionsforhold danner samfundets $\varnothing$ konomiske struktur, den reelle basis, på hvilken der hæver sig en juridisk og politisk overbygning, og hvortil der svarer betemte samfundsmæssige bevidsthedsformer « ${ }^{7}$. Denne $b a$ sis/overbygningsmetafor (som forestiller en bygning) opfattes af Marx som en »ledetråd « og kendes ikke i Marx' teoretiske hovedværk Kapitalen. Den udtrykker eksplicit det materialistiske udgangspunkt også ved analysen af det juridiske system. Retten kan ikke (som hos de borgerlige idealister) forstås ud frasigselv. Retten hviler på sin »basis« og kan ikke forstås uden i sin sammenføjning med denne.

Denne marxske »ledetråd « har i postmarxismen givet anledning til uanede problemer. Hvad hører til basis og hvad til overbygningen? Og hvordan er forbindelsen mellem disse samfundsmæssige lag? Determinerer basis overbygningen eller er der en vekselvirkning og i bekræftende fald af hvilken art? Basis/overbygnings-problemet vil vi se vidt forskelligt behandlet hos de tre forskellige retsteoretiske retninger.

\section{Retten som historisk fænomen.}

Marx siger i Den tyske ideologi, at »retten lige så lidt som religionen har en egen historie $\ll{ }^{8}$ Hermed udtrykkes (ligesom med bygningsmetaforen) det materialistiske grundsyn, men her fremhæves det historiske aspekt: Retten har ingen egen historie, men en (anden) historie der står i et afhængighedsforhold til »basis«.

Rettens historiske betingethed følger således af, »at enhver form for produktion skaber sine egne retsforhold, regeringsform etc. $\ll^{9}$ Det er altså produktionsmåden, der er afgørende for rettens historiske specifitet.

Den borgerlige ret er den kapitalistiske produktionsmådes (det borgerlige samfunds) retsorden. Den borgerlige ret er udviklet sammen med det borgerlige samfund og vil forsvinde sammen med dette samfund. »Retten kan aldrig stå over samfundets $\varnothing$ konomiske struktur og den deraf betingede kulturudvikling. I en højere fase af det kommunistiske samfund ... kan den snævre borgerlige retshorisont helt overskrides $\ll{ }^{10}$ Hos flere retsteoretikere (Paschukanis o.a.) har dette grundsynspunkt ført til en lære om retsformens uddøen. ${ }^{11}$

7. Marx i »Forord « til kritik af den politiske $\varnothing$ konomi, MEUS II, p. 356. For yderligere henvisninger til Marx se N. Reich, (note 4) p. $29 \mathrm{ff}$.

8. MEW 3, p. 27, 63, 312 og 539. Denne udtalelse har tydelig adresse til idealismen hos den tyske historiske skole (Hugo, von Savigny m.fl.). Se nærmere hertil Marx, »Das philosophische Manifest der historischen Rechtsschule«, MEW 1, p. $78 \mathrm{ff}$.

9. Marx, »Indledning « til »Grundrids ...« (note 5) p. 10.

10. Marx, Kritik af Gothaprogrammet, MEUS II, p. $17 \mathrm{f}$.

11. Jfr. N. Reich, (note 3) p. 14 og T. Wanscher (note 1) 


\section{Retten som klasseret.}

»Retten kan aldrig stå over samfundets økonomiske struktur« og »loven er et produkt af de materielle produktionsforhold «, jfr. ovenfor. Rettens indhold er bestemt af den materielle produktion. I en produktionsmåde, der er baseret på klassedeling, er rettens indhold klassebestemt.

»Jeres ideer er selv produkt af de borgerlige produktions- og ejendomsforhold, ligesom jeres retsorden ikke er andet end jeres klassevilje ophøjet til lov, og denne viljes indhold er bestemt af jeres klasses materielle livsbetingelser. ${ }^{12}$ Den borgerlige rets indhold er udtryk for borgerklassens materielle interesser, og den er »kapitalistisk justits $\ll \cdot{ }^{13}$ Den borgerlige ret er i sit indhold og sin funktion $»$ klasseret $\ll$.

\section{III. »Kritisk« retsteori.}

I de senere år er det navnlig den såkaldte »kritiske« teori, ${ }^{14}$ der har påvirket den retsteoretiske diskussion. En del »kritisk « retsvidenskabelig litteratur af mere eller mindre materialistisk karakter har set dagens lys.

»Den intention at rekonstruere den marxistiske retsteori ud fra horisonten hos en moderne fortolket Marx «, ${ }^{15}$ har hos mange forfattere taget sit udgangspunkt i den »kritiske« teori hos Habermas og i dennes særlige kritiske Marxforståelse (»At forstå Marx bedre, end han har forstået sig selv « ${ }^{16}$ ): »Nu knytter denne metakritik imidlertid selv an til Marx og er derigennem legitimeret som marxistisk, da den kun mere konsistent viderefører Marx' tanker: med Marx mod Marx «. ${ }^{17}$

Ifølge Habermas er det nødvendigt at revidere Marx for at kunne skabe en samfundskritisk teori, der kan give mulighed for emancipatorisk refleksion og selvrefleksion henimod et samfund karakteriseret ved en »herrschaftsfreie Diskussion «. Revisionen sker især på to punkter: 1. Kategorierne »arbejde « og »interaktion « indføres i stedet for kategorierne produktivkraft og produktionsforhold. 2. Rationalisering og teknologi opfattes som selvstændige umiddelbare (mer-)værdikilder ved siden af arbejdet. Altså en opgivelse af arbejdsværditeorien.

12. Marx, Det kommunistiske manifest, MEUS I, p. 43. Jfr. også Marx, Den tyske ideologi, MEW 3, p. 311. Det er denne polemiske udtalelse, der har spillet så stor en rolle for udviklingen af en normativ viljeteoretisk retsteori i Sovjetunionen i 30 'erne.

13. Marx, Kapitalen, MEW 23, p. 690. (Rhodos p. 928).

14. Se hertil R. Kalleberg, »Kritisk teori«, Oslo 1970. Habermas, »Vitenskap som ideologi«, Oslo 1969. Samme, »Borgerlig offentlighet «, Oslo 1971.

15. Wolf Paul, »Das Programm marxistischer Rechtslehre - ein kritischer Rekonstruktionsversuch «, p. 201. Trykt i N. Reich (note 3) p. $201 \mathrm{ff}$.

16. Habermas, »Theorie und Praxis«, Frankfurt/M. 1971, p. 244.

17. W. Paul, (note 15) p. 220. 
Den første indvending reducerer produktionsbegrebet til instrumentel handling og overser, at produktionen hos Marx altid omfatter både arbejdsdeling, interaktion, bevidsthed og kommunikation. Den anden indvending bygger på en sammenblanding af begreberne brugsværdi og værdi. ${ }^{18}$

Det programmatiske hovedindhold for den »kritiske « retsteori er: »rekonstruktionen af den marxistiske retsteori som »retskritik«««. ${ }^{19}$ Det er den »kritiske« intention hos den unge Marx, der kan spores hos de »kritiske« retsteoretikere: »Det er først og fremmest den filosofis opgave, der står i historiens tjeneste, at demaskere fremmedgørelsen i dens profane former ... kritikken af religionen forvandles dermed til kritik af retten ... «20.

Her vil blot blive redegjort for de vigtigste og mest karakteristiske træk ved en »kritisk « retsvidenskab i denne teori-tradition.

\section{A. »Kritik«-begrebet.}

»Kritik«-begrebets indhold er ikke entydigt, ${ }^{21}$ men dets elementer kan i vidt omfang føres tilbage til Habermas. Se som eksempler følgende typiske formuleringer:

W. Paul: »...Den marxistiske retsteori er frigørende, interesseret i praktisk-kritisk ophævelse af undertrykkelse (»Herrschaftsabbau«). ...Sammenfattende kan man slå fast, at den marxistiske teori som kritik ifølge sin struktur svarer til en revolutionær historiefilosofi, der formidles gennem det historisk-empiriske materiale, som videnskaberne oparbejder; og som peger frem mod en praksis, hvis forandrende virkninger igen bearbejdes af videnskaben. Den sammenhængende mening i den reale virkelighed rekonstrueres ideologikritisk ud fra de konflikter, som er skjult bag en periodes officielle selvforståelse. Som denne specifikke forbindelse mellem filosofi og videnskab bliver kritik til humanismens revolutionare $k r a f t \ll .{ }^{22}$

H. Zahle: »Jeg tilstræber en indsigt i et kapitalistisk samfunds retssystem, for med denne indsigt som led i en almindelig teori, ud fra de interessser som jeg identificerer mig med, at kunne give bidrag til en frigørende praksis $\ll{ }^{23}$

18. Se nærmere til kritikken af Habermas' Marx-reyision: H.-J. Schanz (note 5) p. 56 ff., og Ritsert og Rolshausen, »Der Konservatismus der kritischen Theorie«, Frankfurt/M. 1971.

19. W. Paul, (note 15) p. 210. Se også N. Reich i Indledningen til Stutschka, »Die revolutionäre Rolle von Recht und Staat« Frankfurt/M. 1969, p. 18: »Kun retskritikken kan i positiv forstand indgå i en efter-marxistisk retsfilosofi.«

20. Marx i »Indledning til kritik af den hegelske retsfilosofi.«Trykt i Witt-Hansen, »Karl Marx«, Kbhn. 1970, p. 52. - Dette citat er brugt som motto for Umberto Cerroni, »Marx und das moderne Recht«, Frankfurt/M. 1974, (Rom 1962), som netop vil rekonstruere den marxske teori som historisk-materialistisk kritik med udgangspunkt i de af postmarxismen forsømte ungdomsskrifter, se f.eks. p. $107 \mathrm{f}$.

21. Jfr. Fagkritisk Front. »Juristen og samfundet«, Århus 1973. p. $100 \mathrm{ff}$.

22. Wolf Paul, (Note 15) p. 203 og $222 \mathrm{f}$.

23. Henrik Zahle, »Kritisk proces«, København 1974, p. 3. 
Nils Kristian Sundby: »... to hovedbetydninger av »kritisk «, en erkjennelsesteoretisk som går tilbake til Kant, og en betydning som er mer direkte politisk handlingsrettet. En tredje, liberalistisk betydning (»studentene må oppfordres til å være våkne og kritiske«), ser jeg bort fra som uinteressant, da den liberalistiske normen om å være kritisk stilltiende tolkes slik at kun kritikk innenfor systemets egne rammer oppmuntres og aksepteres. Som sagt er det hele tiden et kjennetegn for det jeg kaller kritisk retsteori at teoriens tilhengere vil ganske annerledes radikale forandringer i forhold til det bestående «. ${ }^{24}$

Man kan diskutere denne kritiks indhold ud fra 4 aspekter, der i varierende omfang belyser centrale punkter i denne teori:

\section{Erkendelse og interesse.}

»For forskningsprocessens tre kategorier lar det seg påvise en spesifikk sammenhæng mellom logisk-metodiske regler og erkjennelsesledende interesser. Dette er opgaven for en kritisk vitenskapsteori som unngår positivismens fallgruber. I ansatsen til de empirisk-analytiske vitenskaper inngår en teknisk, i ansatsen til de historisk-hermeneutiske vitenskaper en praktisk og i ansatsen til de kritisk orienterte vitenskaper den frigjørende erkjennelsesinteresse. $\ll^{25}$

Denne tese om forholdet mellem erkendelse og interesse danner grundlaget for den »kritiske « retsvidenskap, som jeg vil fors øge at belyse gennem disse 4 aspekter.

Tankegangen er i store træk den, at retten, de retlige institutioner og retsvidenskaben er redskaber i de herskende samfundsgruppers (i mere marxistisk prægede varianter: den herskende klasses) interesse, og redskaber som samtidig tilslører - og dermed legitimerer - dette magtforhold.

Den kritiske retsvidenskabs opgave er derfor at påvise (d.v.s. afsløre) dette gennem »kritik « for herigennem at udøve en frigørende praksis i de undertrykte gruppers (klasses) interesse.

Forklaringsmodellen er som regel blot reduktiv, i den forstand at man har til hensigt »kritisk « at afsløre det materielle eller økonomiske indhold i normen eller ideologien, og hvorved man ofte indskrænker sig til at reducere det behandlede fænomen tilbage til en dybere årsag ved i al almindelighed at henvise til »kapitalismens behov«, »profitmotivet « el.lign.

\section{Frigørelse. (Emancipation).}

Dette begreb er centralt placeret i de ovennævnte citater. Men hvem skal frigøres, og fra hvad og til hvad? Her er uklarheden stor og meningerne delte.

24. Nils Kristian Sundby, »Positivistisk og kritisk jus«, Samtiden 1974, p. 380 ff, p. 383.

25. Habermas, »Erkjennelse og interesse«, p. 9. Trykt i »Vitenskap som ideologi«, Oslo 1969. 
Det menneskelige individ, undertrykte grupper eller proletariatet?

Fra uretfærdighed, fremmedgørelse, undertrykkelse eller kapitalismen?

Til en retfærdig socialstat, »herrschaftsfreie Kommunikation«, socialisme eller proletariatets diktatur?

Det gennemgående træk kan siges at være et ideal om en almenmenneskelig frigфrelse fra »undertrykkelse (herredømme), uden at være specifikt indrettet på proletariatets kamp som klasse mod kapitalens herredømme. Det er den humanistisk-antropologiske kritik-figur hos den unge Marx, der videnskabsgenetisk er dette kritikbegrebs platform. Denne kritik-figurs centrale indhold er påvisningen af menneskets fremmedgфrelse fra det menneskelige vasen. ${ }^{26}$

Følgende citat belyser på udmærket måde opfattelsen af forholdet mellem ret og emancipation hos en typisk repræsentant for Habermasskolen:

»Udviklingen fra herredømmets ret til rettens herredømme betegner skridt for skridt den historiske proces for den almene menneskelige emancipation. ... Marxistisk retsteori ... er, - på grund af sin hensigt at forvandle ideologisk ret til kritisk ret og historisk at virkeliggøre den almene menneskelige emancipation, - den historisk-dialektiske filosofi for evolutionen fra ret til retfardighed. $\ll^{27}$

Og hvorledes kan denne frigørelse ske?

Gennem dialog eller klassekamp?

»Emancipation fremtræder som et spørgsmål om at ophæve forvrængninger i kommunikationsprocesserne og ikke som en befrielse af kollektive grupper, som er underkastet konkret undertrykkelse. Følgerigtigt bliver derfor (kritisk) sociologi opfattet som »emancipatorisk engageret ideologikritik «. $\ll^{28}$

Den frigørende (»kritiske«) virksomhed for »kritiske« jurister sker gennem »retskritik«, jfr. punkt 3, d.v.s. ideologikritik (jfr. punkt 3a), konkret retskritik, altså indholdskritik (jfr. punkt 3b) og positivismekritik, det vil her sige dogmatikkritik (jfr. punkt 3c), og gennem praksis«, jfr. punkt 4.

\section{Retskritik.}

Den følgende tre-deling angiver naturligvis ikke skarpt afgrænsede forskellige »kritik«-former, men i inddelingen focuseres på forskellige elementer, der som regel alle indgår i den »kritiske « analyse blot med forskellig vægt alt efter analysens intention og objekt.

26. Se nærmere hertil Ranciere, »Kritikbegrebet og kritikken af den politiske $\varnothing$ konomi«, rhus 1973 (original Paris 1965).

27. Wolf Paul (note 15), p. 228

28. Ritsert/Rolshausen, (note 18), p. 88. 


\section{a. Ideologikritik.}

»En kritisk samfunnsvitenskap ... påtar seg ... å undersøke når de teoretiske utsagn griper invariante lovmæssigheter ved den sociale adferd overhodet og når den griper ideologisk fastfrosne, men i prinsippet foranderlige avhængighetsforhold. I den grad dette er tilfældet regner ideologikritikken - som for øvtig psykoanalysen - med at informasjon om lovsammenhenger utløser en refleksjonsprosess i bevidstheten til angjeldende person selv; derigennem kan det ureflekterte bevissthetsniveau, som hører til utgangsbetingelserne for slike love, bli forandret. En kritisk formidlet viten om lover kan via dette gjenom refleksjon om ikke ophæve loven, så iallfall gjøre at den ikke kan anvendes $\ll{ }^{29}$

Dettte udgangspunkt hos Habermas om sammenhængen: ideologikritik - selvrefleksion - frigфrelse er vigtigt for forståelsen af den centrale rolle, som ideologikritikken spiller i den kritiske retsvidenskab.

Det er nemlig karakterisktisk, at rettens ideologiske karakter stærkt fremhæves. Denne opfattelse kan føres tilbage til Marx/Engels, hvor ideologien er den falske, fordrejede (borgerlige) bevidsthed. ${ }^{30}$

Og utallige steder fremhæver Marx/Engels sådanne ideologiske momenter i den borgerlige ret. Det ideologiske (falske, fordrejede, illusionære, mystificerende ...) refererer sig overvejende til en idealistisk retsopfattelse ${ }^{31}$ og til de retlige formers og nøglebegrebers tilsløring af rettens $\varnothing$ konomiske indhold. ${ }^{32}$

Afsloringen af de ideologiske momenter bliver en vigtig opgave for den kritiske retsvidenskab, ofte endda den vigtigste. Et typisk eksempel er afsløringen af den ideologiske karakter ved de retlige grundbegreber om »frihed « og »lighed « gennem henvisningen til den faktiske sociale ulighed (klassedeling) i samfundet og gennem påvisningen af frihedens og lighedens økonomiske indhold, nemlig ækvivalensen i det simple varebytte.

Det vil i mange tilfælde være berettiget at tale om en ideologifetischering ${ }^{33}$, som overvurderer den ideologiske, altså bevidsthedsmæssige, funktion af retten i forhold til retssystemets reale funktioner i samfundstotalitetens reproduktionsproces, jfr. nedenfor om materialistisk retsteori.

Hos nogle forfattere bliver retssystemet ligefrem reduceret til ideologi. F.eks. hos Norbert Reich: »Retten har ingen fra ideologien i klassesamfundet løsrevet

29. Habermas (note 25) p. 11. Sammenlign hertil analysen og metakritikken af det Habermasske kritikbegreb hos Ritsert/Rolshausen (note 18) p. 94: »Efter dette mønster findes ikke anden bekræftelse på kritikken end den ved dialog bibragte selvrefleksion hos de deltagende, - klassekamp bliver i det store og hele til psykoterapi.«

30. Jfr. f.eks. Engels' brev til Mehring, MEUS II, p. 498. »Ideologien er en proces, som det såkaldte tænkende menneske ganske vist fuldbyrder med bevidsthed, men med en falsk bevidsthed «.

31. Se f.eks. Marx i Den tyske ideologi, MEW 3 p. 311-12 og Engels i breve til Schmidt og Mehring, MEUS p. 405 og 498-99.

32. Se f.eks. Marx i Kapitalen, MEW 23, p. 190 og 562 (Rhodos p. 292 og 762).

33. Jfr. Fagkritisk front (note 21) p. 103. 
eksistens, « ${ }^{34}$ og hos Peter Blume: »...dette udgangspunkt må være af marxistisk beskaffenhed, hvilket indebærer, at retten opfattes som en ideologi, ...« og: »Domstolene er en del af den retlige ideologi $\ll^{35}$, hvor selv retlige institutioner gøres til bevidsthed. ${ }^{36}$

Opfattelser af denne art forøger ikke just kritikkens frigørende kraft og har intet grundlag i den marxske teori, hvor ideologien altid blot fremhæves som et aspekt ved den borgerlige ret.

\section{b. Indholdskritik.}

Indholdskritikken af retssystemet og dets institutioner har primært til hensigt at påvise konkrete reglers og institutioners $\varnothing$ konomiske indhold og funktioner gennem påvisningen af deres interessebestemte (klassebestemte) karakter. Det er især den private ejendomsret og den hermed sammenhængende ulighed og undertrykkelse, der står i centrum for kritikken. ${ }^{37}$

Som eksempel på en konkret kritisk analyse af domstolsorganisationen kan nævnes den tidligere omtalte $H$. Zahle, »Kritisk proces«, København 1974. I øvrigt henvises til neden for $\mathrm{i}$ afsnit VI.

Kritikken af den borgerlige rets form ser man sjældent inddraget $\mathrm{i}$ analysen $\mathrm{i}$ modsætning til de to andre »skoler «. Dette falder i tråd med denne retnings overvejende anknytning ved Marx' ungdomsskrifter, jfr. Engels brev til Mehring i 1893: »Derved fik den indholdsmæssige side os dengang til at forsømme spørgsmålet om formen $\ll .{ }^{38}$

Da det er den private ejendomsrets samfundsmæssige funktioner, man vil blotlægge (afsløre), må man nødvendigvis tage andre (og almene) samfundsvidenskabelige metoder i anvendelse, hvorved indholskritikken i sig selv er forskningslogisk forbundet med en overskridelse af den traditionelle retsdogmatik, - den fører altså over i en »dogmatik-kritik«, jfr. punkt c.

34. Norbert Reich, (note 19) p. 11.

35. Peter Blume, »Et par retsfilosofiske bemærkninger«, Juristen 1973, p. 319 og p. 321.

36. Se også Ole Krarup, Efterskrift til »Juristen og samfundet«, Århus 1973 p. 108, hvor lovene både er »uvirkelige« og hører til bevidsthedsfæren, og Elwin og Victor, »Rättsteori och dialektisk materialism«, Häften för kritiska studier, 1973, hefte 4, p. 33.

37. Jørgen Dalberg-Larsen, (»Introduktion til almindelig retslære« ved Jes Bjarup og Jørgen Dalberg-Larsen, Århus 1973, p. 134 ff.) anviser som en vigtig opgave for en kritisk retsvidenskab at analysere de »negative kendsgerninger «: »Når man f.eks. har generelle regler om sikring af borgernes rettigheder, hvordan kan det da være, at disse ikke modsvares af mere detaillerede regler, der følger de generelle principper op, og hvis sådanne regler findes, hvorfor har man da ikke i retspraksis sørget for deres gennemførelse.« (p. 156).

38. MEUS II, p. 498. 


\section{c. Dogmatikkritik.}

Den kritiske teoris positivisme-kritik har givet sig udslag i en kritik af den retsvidenskabelige dogmatik og den bagvedliggende videnskabsteori, retsfilosofien. ${ }^{39}$

Retsvidenskaben som helhed opfattes som et magtinstrument for de herskende i samfundet gennem sin konservative accept af den givne samfundsstruktur og den dermed sammenhængende »tekniske« erkendelsesinteresse $\mathrm{i}$ at sikre det kapitalistiske samfunds fortsatte eksistens, som giver sig udslag i, at retsdogmatikken kommer til at udgøre retsvidenskabens egentlige kerne. Derved udelukkes rettens samfundsmæssige aspekter (indhold og funktioner) fra retsvidenskaben, som altså centreres snævert om retssystemets egen indre sammenhæng. Den »frigørende« erkendelsesinteresse fører således til en overskridelse af retsdogmatikken.

Retsfilosofien kritiseres for sit positivistiske grundlag, herunder især videnskabsidealet om den $»$ værdifri forskning $\aleph^{40}$ og den videnskabsteoretiske legitimation af retsdogmatikken. Se hertil Henrik Zahle, som igennem et grundigt detailstudium tager »sigte på at påpege de politiske bindinger, som en sådan pretention om værdifrihed kun tilslører«. Retsteoriens politiske funktion påvises ved at fremhæve diskrepansen mellem retsteoriens forståelse af retsdogmatikken som upolitisk (deskriptiv, objektiv) og retsdogmatikkens faktiske bindinger til det »gældende system « og »de magthavendes interesser ${ }^{4}{ }^{41}$

Den juridiske dogmatik $i$ sig selv opfattes som et tilslørende, altså ideologisk, undertrykkelsesinstrument. Jfr. Ole Krarup, som ud fra en intention om at være med til at »bane vej for et hårdt tiltrængt opgør med den borgerlige ideologis tyranni« konkluderer, at vi her står »overfor et slående eksempel på forvansket virkelighedsopfattelse: Den juridiske bevidsthed, som den finder udtryk i begrebsdannelsen, indeholder en sløret, fordrejet gengivelse af det virkelige forhold « ${ }^{42}$

\section{Praksis.}

»I modsætning til traditionel retspolitik, som i første række går ud fra rettens systemaffirmative modalitet, som garanterer og stabiliserer den bestående politøkonomiske praksis, postulerer Marx en systemkritisk og systemaendrende modalitet, som sigter mod verdensforandring. «3 Denne tankegang går tilbage til Marx’ berømte teser om

39. Se afsnittet »Retsvidenskaben begynder, hvor retsdogmatikken holder op« i Fagkritisk Front (note 21) p. $98 \mathrm{ff}$.

40. Jfr. Flemming Deleuran, »Om kritiske jurister (og studenter) og kritisk retsvidenskab«. Juristen 1973 p. $416 \mathrm{ff}$.

41. Henrik Zahle, »Kritik af en retsteori. Om Alf Ross' opfattelse af retsvidenskaben«, Tidsskrift for Rettsvitenskap, 1974, p. $333 \mathrm{ff}$.

42. Ole Krarup, »Om den offentlige rets grundbegreber«, Juristen 1974, p. 349 ff. Jfr. hertil Alf Ross, »Brev til Ole Krarup«, Juristen 1975 p. 1 f. og Ole Krarup, »Om materialistisk retsteori«, Juristen 1975 p. 3 ff., hvor Krarup uddyber sin kritik af retsfilosofien og retsdogmatikken for deres tilslørende (og dermed politiske) funktioner igennem den positivistiske virkelighedspartering (den skarpe grænse mellem de juridiske discipliner, især sondringen retsfilosofi, retssociologi, retsdogmatik) og koncentrationen om overfladefænomener i modsætning til de basale menneskelige relationer.

43. W. Paul (note 15) p. 23. 
Feuerbach, ${ }^{44}$ hvori den »revolutionerende praksis« fremhæves som nødvendig i samspil med den kritiske teori.

Habermas' analyse af formidlingsforholdet mellem teori og praksis taler om et dobbelt forhold:

»Teorien omfatter altså et dobbelt forhold mellem teori og praksis: den undersøger på den ene side den historiske konstitutionssammenhæng for en interessesituation, som teorien så at sige gennem erkendelsen selv tilhører; og på den anden side den historiske aktionssammenhæng, i hvilken teorien kan virke handlingsorienterende. I det første tilfælde drejer det sig om den sociale praksis, der som samfundsmæssig syntese muliggør erkendelse; i det andet tilfælde om en politisk praksis, som bevidst sigter mod en omvæltning af det bestående institutionssystem. ${ }^{45}$

Praksis-kategorien er her stadig central, men er ikke udelukkende politisk revolutionær. Den »sociale praksis« er af mere erkendelsesteoretisk karakter.

Denne todeling af teoriens praksisformidling (og dermed også af kritikbegrebet) viser sig hos Sundby: Den kritiske teori i den første betydning skal »bidra til respekt for og kunnskap om sannheten « og den anden form skal indgå »i arbeid for politiske forandringer ... som kan regnes som »progressive« i forhold til det endelige mål: gjennomføringen af socialismen $\ll^{46}$

Men da der i den »kritiske« teoris humanistisk-antropologiske kritik begreb indgår forestillingen om, at kritikken i sig selv er »humanismens revolutionære kraft $\ll,{ }^{47}$ er det teori/praksis-formidlingen i den f $\phi$ rste betydning, der er den dominerende. Dette har bl.a. vist sig ovenfor i afsnit 3, om »Retskritik«.

Hermed bliver »praksis«-begrebet bestemt: Praksis som kritik.

\section{B. Materialisme-opfattelse.}

De fleste forfattere af denne skole bekender sig til en videnskabelig materialisme. Men hvad er indholdet af dette? »Synspunktet er materialistisk fordi det tilstræber at forklare de procesretlige normer som led i en samfundsmæssig helhed... De må ses i deres vekselspil med andre sociale faktorer, og analysen er baseret på de antagelser, at procesretten som ideologisk og bevidsthedsmæssigt element $\mathrm{i}$ en overbygning $\mathrm{i}$ hovedsagen er afledt af materielle forhold, omend

44. MEUS II, p. 401.

45. Habermas, (note 16) p. 10

46. Nils Kristian Sundby (note 24) p. 386.

47. Wolf Paul (note 15) p. 223. 
ikke uden mulighed for selvstændige forl $\varnothing \mathrm{b} \ll{ }^{48}$ Denne opfattelse af materialismen er repræsentativ for en stor del af den »kritiske« retslitteratur.

Det ses, at hverken de materielle forhold selv eller deres samspil med andre samfundsmæssige faktorer er nøjere teoretisk bestemt, hvilket er karakteristisk for den »kritiske« teori. »Ganske vist ... fører disse forfattere en materialistisk forståelse med sig i argumentationen, men materialismen konstituerer den ikke. Tværtimod kan man tale om en skæbnesvanger »interferens af paradigmer«: det sprogfilosofiske interaktionsbegreb, emancipation som dialogisk proces og interesse-udlicitering som systemproblem forråder en konstitutiv forbindelse til handlingsteori og funktionalisme. I forhold hertil etablerer de kun retoriske henvisninger til den historiske materialisme en svævende aura af kritik. ${ }^{49}$

Den ovenfor under III Al omtalte reduktive forskningslogik hænger nøje sammen med en sådan materialisme-opfattelse. Men det materialistiske videnskabsbegreb hos Marx (som man jo påberåber sig) har et andet indhold: »Det er i realiteten langt lettere gennem analyse at finde de religiøse tågedannelsers jordiske kerne, end omvendt at udvikle de himmelgjorte former af de respektive virkelige livsforhold. Men det sidste er den eneste materialistiske og derfor videnskabelige metode. $« 50$

Denne videnskabs-intention om materialistisk udledning, som Marx gennemf $\varnothing$ rer i sin »kritik af den politiske $\varnothing$ konomi « ${ }^{51}$ fastholdes ikke af den »kritiske« retsvidenskab, men er udgangspunktet for den »materialistiske « retsteori, jfr. nedenfor.

Også den »strukturalistiske « retsteori, jfr. nedenfor, forsøger en teoretisk bestemmelse af det materialistiske grundsyn, nemlig gennem begrebet » $\varnothing$ konomiens determinans i sidste instans « $\mathrm{i}$ en »social struktur $\ll$.

Fastholdes den marxske materialistiske videnskabsteori er Habermas' Marx-»revision « en idealistisk, borgerlig teori. ${ }^{52}$

For den i forlængelse af Habermas udviklede »kritiske« retsteori, f.eks. hos W. Paul, gælder det samme. Det ovenfor ved note 27 anførte citat bygger på et rent idealistisk og dermed borgerligt retsbegreb: Rettens herredømme betegner

48. Zahle (note 23) p. 3. - Se også Elwin/Victor (note 36) p. 35 og Krarup (note 42, 1974) p. 360, der begge i hovedsagen giver udtryk for en tilsvarende materialisme-opfattelse. Krarup (note 42, 1975) p. 4f. betragter dog ikke sin analyse som materialistisk og erkender dermed den »kritiske « analyses utilstrækkelighed og peger frem mod den egentlige materialistiske analyse. H. Zahle (note 41) opfatter heller ikke sin kritik af Ross som materialistisk (p. 403), men indskrænker sig til en påvisning af »at Ross' rets- og statsopfattelse ... er knyttet til den tidlige liberalistiske statsopfattelse « (p. 361).

49. Ritsert/Rolshausen (note 18) p. 10.

50. Kapitalen, MEW 23, p. 393, (Rhodos p. 547). Se også den fjerde Feuerbach-tese.

51. Jfr. H.-J. Schanz (note 5), især afsnittet p. $20 \mathrm{ff}$ : »Det materialistiske grundsyn og kritikken af den politiske $\varnothing \mathrm{konomi} \ll$.

52. Jfr. E. Osborg, »Zum Verhältnis von Recht und Politischer Ökonomie. Ansatz zu einer materialistischen Rechtstheorie«, Frankfurt/M 1972 (endnu utrykt dissertation), som kritiserer den »»nicht-marxistischen« Marxverständnis« hos Habermas som en »idealistischen Konstrukt«, p. 153 og 210. 
menneskets frigørelse, som sker ved hjælp af teoriens forvandling af den ideologiske ret til kritisk ret og til retfærdighed! - Her er retsbegrebet ikke materialistisk opfattet som det borgerlige samfunds ret, men er en rent tænkt retside, som repræsenterer en højere retfærdighed, men som dog kan virkeliggøres gennem kritisk udviklingsarbejde - uden en revolutionær overvindelse af kapitalismen. (Er det her den Habermas'ske retfærdige »socialstat«, han tænker på?)

\section{De tre grundproblemer.}

Vi kan herefter se på, hvilken stilling den »kritiske« retsteori indtager over for de 3 hovedtemaer i marxistisk retsteori.

\section{Retten som overbygning.}

Anvendelsen af de billedlige analysebegreber »basis« og »overbygning«, som hos den unge Marx udtrykker den materialistiske intention, går igen som et kernepunkt $i$ hele den post-marxistiske retstradition..$^{53}$ Også hos den kritiske retsteori genfinder vi brugen af denne bygningsmetafor. Billedet bruges, da det på en nem og bekvem måde giver udtryk for den materialistiske selvforståelse.

Den teori, der ligger bag den reduktive forskningslogik, med dens søgen efter dybere liggende generelt formulerede årsager, tenderer mod en deterministisk opfattelse af forholdet mellem basis og overbygning, d.v.s. at overbygningen betragtes som en afspejling af basis. Som regel karakteriseres dette forhold dog somet $\gg$ vekselspil« eller en »vekselvirkning « men uden nogen præcisere teoretisk fastlæggelse heraf - og slet ikke polit- $\phi$ konomisk reflekteret.

Selv om »kritikken« primært går ud på at afsløre det materielle, økonomiske, indhold i retssystemet, kan man påvise en tendens til oppustning af overbygningens og dermed rettens samfundsmaessige rolle. Dette kan f.eks. konstateres i den stærke - næsten udelukkende - vægt, der lægges på kampen mod den borgerlige ideologi, i bestemmelsen af praksis som kritik, og hos W. Paul, som via et begreb som »kritisk ret« o.lgn. helt ender i en idealistisk position.

Denne idealistiske tendens er udtryk for en videnskabslogisk uklarhed, idet den ikke med konsistens lader sig forene med den reduktive forskningslogik, hverken i dennes mere deterministiske eller mere vekselvirkningsorienterede varianter.

\section{Retten som historisk fænomen.}

I overensstemmelse med den »kritiske« teoris overvejende anknytning ved Marx tidligere skrifter, i modsætning til Marx’ senere »kritik af den politiske $\varnothing$ konomi«,

53. Renner, Paschukanis, Stutschka, Korsch, Marxismen-Leninismen o.s.v. 
knyttes det historiske perspektiv ofte ${ }^{54}$ til udtalelserne i Den tyske ideologi, om at retten ikke har nogen egen historie.

Men det historiske perspektiv er ikke polit- $\phi$ konomisk reflekteret. Udviklingen af det borgerlige samfund bliver ikke materialistisk konsekvent reflekteret igennem kapitalforholdets konstituering. Dette kan f.eks. tydeligt ses hos Habermas, hvor borgerskabets offentlige og politiske fremtræden tilskrives en afgørende rolle for kapitalismens fremvækst, hvorimod f.eks. den oprindelige akkumulation overhovedet ikke er nævnt. ${ }^{55}$

»Kritikken«, som den er analyseret ovenfor, lægger ikke nogen hovedvægt på det historisk specifikke, og hos W. Paul, - se citatet ved note 27 - er rettens historiske betingethed forvandlet til en idealistisk »historicitet «, som nærmest er af metafysisk, naturretlig art, og dermed ahistorisk.

\section{Retten som klasseret.}

Den oven for påviste reduktive forskningslogiks typiske træk er netop afsløringen af rettens interessebundethed til fordel for den herskende klasse. At afsløre retten og dens institutioner som klasseredskaber (klasseret og klassedomstole) er hovedindholdet i både ideologi-, indholdsog dogmatikkritikken. Retten fungerer i overvejende grad som klasseret ved sin ideologiske karakter, men også ved opretholdelsen af social ulighed gennem beskyttelsen af den private ejendomsret.

Men hvad er en »klasse«? I virkeligheden dækker der sig ofte bag begrebet om »klasseret « blot en forståelse for rettens interesse-betonede karakter, hvilket enhver borgerlig (rets-) sociolog er klar over. Dette hænger sammen med »klasse«-begrebets manglende polit- $\phi$ konomiske begribelse. Ritsert og Rolshausen hentyder således med titlen: »Der Konservativismus der kritischen Theorie « til »ophævelsen af interessen i en politøkonomisk begrundet klasseanalyse, uden at den praktiske ophævelse af antagonismen mellem lønarbejde og kapital har fundet sted. $\ll^{56}$

Med brugen af »klasse«-begrebet menes i virkeligheden ofte blot »indtægtsgrupper«, »parlamentarisk-politiske partier« o. lign. og ikke kapital-logisk udledte klasser, selv om man anvender kategorier som »kapitalistklasse « og »arbejderklasse «. Og med »klasse-interesser« menes i virkeligheden ofte interessegruppernes og partiernes »ligeligere-fordelingssynspunkt « og ikke de kapital-logisk udledte objektive klasseinteresser, som for arbejderklassen er kapitalforholdets totale ophævelse.

Et eksempel: »Störst blir naturligtvis möjligheten att påverka lagstiftningen $\mathrm{om}$, såsom länge varit fallet $i$ vårt land, arbetarklassen innehar regeringsmagten«. Eklund vil »förbehålla begreppet klasslag åt sådan lag som en samhälls-

54. F.eks. W. Paul (note 15) p. 211 og N. Reich (note 19) p. $17 \mathrm{f}$.

55. Se Habermas »Borgerlig offentlighet«, Oslo 1971.

56. Ritsert og Rolshausen (note 18) p. 10. 
klass tillgriper för att vinna, stärka eller vidmakthålla en maktställning över en anden samhällsklass... Det är klasslagstiftning av denna negative karaktär - den som vände sin udd mot arbetarrörelsen - som skall behandlas i denna avhandling. Utanför behandlingen faller sådan »positiv « klasslagstiftning som i regel framtvingad av de sämre lottade samhället. Det må slutligen anmärkas att en positiv klasslagstiftning som skapas av den härskande klassen för att dämpa oron hos misgynnade eller förtrykta samhällsklasser kan ses som en negativ klasslagstiftning, eftersom den ytterst avser att bevara den härskande klassens privilegierade ställning. Känt är att Bismarck på sin tid genomdrev en sociallagstiftning i syfte att motverka den tyske socialdemokratins frammarsch $\ll,{ }^{57}$ (mine fremhævelser).

Her er »klasselovs«-begrebet knyttet til parlamentarisk-politiske partiers fordelings-interesser, subjektiviserede taktik og indbyrdes magtforhold.

»Arbejderklassen« er her identisk med socialdemokratiet!

\section{Strukturalistisk retsteori.}

»Imidlertid kan retsteori kun konstitueres som videnskab, hvis den bestemmer sit erkendelsesobjekt »ret« og betragter ret som »ret«, ikke som middel til emancipation eller som et emancipationsforhindrende relikt. Først da bliver retsteori til genuin videnskabelig kritik af objektet »ret« som »teoretisk praksis.«« ${ }^{58}$

Med en opfattelse som denne udtrykkes et helt andet teoretisk udgangspunkt end hos den »kritiske« teori. Det er ikke her »retsteori som emancipation«, men som »teoretisk praksis«. Det er dog også her »retsteori som kritik«, men først igennem rettens teoretiske bestemmelse som »erkendelsesobjekt«.

\section{A. »Struktur«-begrebet.}

\section{Den »teoretiske praksis« og »erkendelsesobjektet«.}

Det er Althussers strukturalistiske Marx-tolkning, der er udgangspunktet for denne teoretiske retning. ${ }^{59}$ Ifølge Althusser udgør teorien en praksis, der gennem teorien

57. Per Eklund, »Rätten i klasskampen«, Stockholm 1974, p. 29 ff.

58. N. Reich (note 2) p. 39. I denne artikel argumenterer N. Reich for den struk turalistiske Marxtolkning og ændrer dermed opfattelse (eksplicit i note 1 og 10) i forhold til sit tidligere teoretiske ståsted, som nærmest var i overensstemmelse med den »kritiske« retsteori, jfr. ovenfor i note 19 og ved note 34 .

59. Althusser, »Pour Marx«, Paris 1965 (oversat til dansk »For Marx«, Kbhn. 1969) og Althusser/ Balibar, »Lire le Capital«, Paris 1965, (oversat til svensk, »Att läsa Kapitalet«, bd. 1 og 2, Staffanstorp 1970). Specielt om politisk teori: Poulantzas, »Pouvoir politique et classes sociales«, Paris 1968 (oversat til svensk: »Politisk makt och sociale klasser«, Mölndal 1970). 
forvandler ideologi til erkendelse. Den »teoretiske praksis« er den videnskabelige erkendelses-proces. ${ }^{60}$

Det erkendelsesteoretiske grundlag er fremhævelsen af »erkendelsesobjektets « (som »tankeobjekt«) forskellighed fra »realobjektet«: Althusser opretholder skarpt (med henvisning til Marx i »Indledning « til »Grundrids...«) distinktionen mellem »det tanke-konkrete, der er erkendelse, og det virkeligheds-konkrete, der er dens objekt. Den proces, der producerer den konkrete erkendelse, foregår helt og holdent inden for den teoretiske praksis: »den angår naturligvis det virkeligheds-konkrete, men dette virkelighedskonkrete »eksisterer uafhængigt videre som før uden for tanken« (Marx), hvor det ikke nogensinde må blandes sammen med dette andet »konkrete «, som erkendelsen af det er «. ${ }^{61}$

For at den teoretiske praksis kan producere denne erkendelse må videnskaben »udarbejde sine egne videnskabelige kendsgerninger gennem en kritik af de ideologiske »kendsgerninger «, der er udarbejdet af den tidligere ideologiske teoretiske praksis. At udarbejde sine egne specifikke »kendsgerninger«, det er samtidig at udarbejde sin egen »teori«, eftersom den videnskabelige kendsgerning - og ikke det såkaldte rene fænomen - kun bliver identificeret i den teoretiske praksis' felt «. ${ }^{62}$

For en teori om retten har det til konsekvens, »at muligheden for en særlig teori afhænger af dens objekts autonomi og specifitet, ikke i den sociale empiriske virkelighed, men som objekt konstrueret af denne teori som objekt for teoretisk undersøgelse. En marxistisk retsteori har kun krav på gyldighed i den udstrækning den konstituerer sit eget objekt. $\ll^{63}$

Denne konstituering sker gennem »struktur«-begrebet, som gennem en »symptomal lasning « læses ind $\mathrm{i} »$ den modne MarX «. ${ }^{64}$ Den symptomale læsning ${ }^{65}$ koncentrerer sig om en teksts lakuner (»hvide pletter «) og rekonstruerer tekstens eget nærværende-fraværende ubevidste, hvilket hos den modne Marx netop er »struktur «-begrebet. Der kan nemlig i det marxske værk konstateres et »epistemologisk brud «, der betegner udviklingen fra den unge Marx' før-videnskabelige (ideologiske) hegelske og feuerbachske begrebsverden til den modne Marx' videnskabeligt materialistiske »struktur«-teori, (som altså hos Marx er ikke-erkendt tilstede).

\section{Skitse over »struktur«-begrebets elementer.}

»For den modne Marx består en social struktur, en produktionsmåde eller en samfundsformation, af et sæt af særlige og specifikt virkende niveauer, der i

60. Se til de erkendelsesteoretiske problemer især »For Marx« (note 59) p. 146 ff, og 156 ff, og »Att läsa ...« bd. 1 (note 59) p. 50 ff.

61. »For Marx« (note 59) p. 159.

62. »For Marx« (note 59) p. 157.

63. Poulantzas (note 3) p. 76.

64. I modsætning til den »kritiske« retsteoris forankring hos den unge Marx.

65. Se »Att läsa ...« bd. 1. (note 59) p. 31 ff. og 102. 
sidste instans er determineret af $\varnothing$ konomien $\aleph^{66}$. De fire grundlæggende niveauer er det $\varnothing$ konomiske, det politisk-juridiske, det ideologiske og det teoretiske, med hver sin praksis. Disse niveauer udgør regionale strukturer, som er relativt autonome. - Herigennem er retten konstitueret som særligt videnskabeligt erkendelsesobjekt.

Disse regionale strukturer findes i enhver social struktur, og det er altid $\phi k o n o-$ miens determinans $i$ sidste instans, som afgør hvilket niveau, der spiller den dominerende rolle.

En produktionsmåde er den teoretisk rene struktur, hvorimod en samfundsformation udviser en historisk bestemt kombination af flere produktionsmåder med en bestemt produktionsmådes dominans.

Det komplekse samspil mellem en struktur og dens elementer udgør en strukturel (»metonymisk «) kausalitet, i modsætning til en lineær, mekanisk kausalitet ${ }^{67}$ og overdetermination betegner en strukturs dominans over en anden struktur og dens elementer. ${ }^{68}$

\section{Formanalyse.}

Det er først og fremmest rettens form og almene (strukturelle) funktioner, som har interesseret de forfattere, der har anvendt det Althusserske »struktur«-begreb ved retsteoretiske analyser. F.eks. i følgende karakteristiske formulering: »Vi vil i det følgende angive de strukturelle betingelser juraen er underlagt i den kapitalistiske produktionsmåde. Herved kan vi påvise nogle grundlæggende former for det juridiske system; men ikke vise hvordan det juridiske system selv udvikles indenfor disse rammer ${ }^{6}{ }^{6}$

\section{Den kapitalistiske produktionsmåde.}

Den kapitalistiske produktionsmåde ${ }^{70}$ er karakteriseret ved en specifik autonomisering af det $\varnothing$ konomiske og det politisk-juridiske niveau. Dette skyldes adskillelse mellem producent og produktionsmiddel (både i den reelle tilegnelsesrelation og $\mathrm{i}$ ejendomsforholdet) i det $\varnothing$ konomiske niveau, som altså ikke behøver ikke- $\varnothing$ konomiske tvangsmidler, for at ikke-arbejderen kan aftvinge arbejderen merarbejde. Det

66. Poulantzas (note 3) p. 82.

67. Se »Att läsa«, bd. 2 (note 59) p. 62 ff., f.eks. p. 69: Orsakens frånvaro i strukturens »metonymiska kausalitet « på sina effekter är inte resultat av strukturens exterioritet (egenskap att vara något yttre) i förhållande til de ekonomiska fenomenen: det er tvärtom själva formen för strukturens interioritet (egenskap att vara något inre) såsom struktur i sina effekter.«

68. Se »For Marx« (note 59) p. $173 \mathrm{ff}$.

69. Lisbet Roepstorff, »Det juridiske systems dominans i den kapitalistiske ideologi«, Kurasje nr. 10, p. 87. Det sagte gælder også for Poulantzas (note 3).

70. Jfr. til dette afsnit især Ballibar i »Att läsa«... bd. 2, p. 84 ff og Poulantzas (note 3 og note 59). 
følger derfor af $\varnothing$ konomiens determinans i sidste instans, at det $\emptyset$ konomiske niveau også spiller den dominerende rolle. ${ }^{71}$

I prakapitalistiske produktionsmåder er producenten ikke i den reelle tilegnelsesrelation adskilt fra sit produktionsmiddel, hvorfor det er nødvendigt med ikke- $\varnothing$ konomiske (religiøse eller politisk-juridiske) tvangsmidler til afpresningen af merarbejdet. Derfor ses en tæt sammenvaevning af niveauerne, og at de ikke$\emptyset$ konomiske niveauer spiller den dominerende rolle, hvilket også her følger af økonomiens determinans i sidste instans.

Rettens specifikke autonomisering i den kapitalistiske produktionsmåde muliggør den teoretiske bestemmelse af retten i denne struktur. Poulantzas kan »konstruere det teoretiske begreb om den moderne ret som et system af normer, der er generelle, abstrakte, formelle og nøjagtigt regelsatte i den forstand, at de besidder en fuldstændig reversabilitet $\ll^{72}$

\section{Reproduktion og funktion.}

Det er med udgangspunkt i kategorien om samfundets reproduktion at overbygningens, herunder rettens, almene (strukturelle) funktioner søges analyseret: ${ }^{73} \gg$ Hvordan sikres reproduktionen af produktionsforholdene? Den er for en meget stor dels vedkommende sikret af den juridisk-politiske og ideologiske overbygning « $^{74}$ Institutionelt tilhører det juridiske system samtidigt det repressive statsapparat, der overvejende fungerer på vold, og systemet af ideologiske statsapparater, der fungerer på ideologi. ${ }^{75}$

\section{Ideologien og retten.}

At fungere på ideologi vil sige at bidrage til strukturens bevidsthedsmæssige legitimering hos strukturens subjekter, da »ideologien repræsenterer individernes imaginære forhold til deres virkelige eksistensbetingelser $\ll .{ }^{76}$ Althusser's tese om ideologien er, »at det er i og under den ideologiske underkastelses former, at reproduktionen af arbejdskraftens kvalifikation er sikret « ${ }^{77}$, hvorfor »skolen (og parret skole-familie) konstituerer det dominerende ideologiske statsapparat $\ll^{78}$.

71. Dette har dog ifølge strukturalisterne kvalitativt ændret sig under statsmonopolkapitalismen som specifik kapitalistisk formation, hvor det politiske niveau spiller den dominerende rolle, jfr. Poulantzas (note 59) p. $233 \mathrm{ff}$.

72. Poulantzas (note 3) p. 98.

73. Althusser, »Ideologi og ideologiske statsapparater«, Kbhvn./Århus 1972, p. 15 ff., 24 og 36 ff. og Roepstorff, (note 69) p. 82 og 84. Disse forfattere udgår begge fra den simple reproduktion (Althusser p. 15, Roepstorff p. 83), som angiver de almene formmæssige betingelser for al reproduktion. Da kapitalistisk reproduktion kun kan foregå som udvidet reproduktion, altså akkumulation, er det klart at denne strukturelle og formelle analyse kun kan have begrænset forklaringsevne over for kapitalistisk udvikling.

74. Althusser (note 73) p. 36.

75. Jfr. Althusser (note 73) p. $30 \mathrm{ff}$.

76. Althusser (note 73) p. 49.

77. Althusser (note 73) p. 21.

78. Althusser (note 73) p. 44. 
Hvad er da indholdet $i$ den kapitalistiske produktionsmådes ideologi? Hos Roepstorff er netop dette spørgsmål genstand for undersøgelse. Hun konkluderer, at den juridiske, specielt den kontraktretlige, ideologi er den dominerende i den kapitalistiske ideologi, da retssystemet både opfylder den vigtige sammenholdsfunktion i den $\varnothing$ konomiske struktur (gennem den private ejendomsret og den frie kontrakt) og den legitimerende funktion (gennem centreringen om det frie og lige individ og de fælles interesser, altså tilsløring af klasseforholdet). Derfor er den off. debat, filosofiske, moralske, religiøse og lign. problemer domineret af juridiske begreber som retfærdigheds-, ligheds- og ansvarsforestillinger ${ }^{79}$.

\section{B. Materialisme-opfattelse.}

Hos strukturalisterne udtrykkes det materialistiske udgangspunkt igennem kategorien: »det фkonomiske niveaus determinans $i$ sidste instans«. Formuleringen er hentet fra Engels: »Den politiske, retslige, filosofiske, religiøse, kunstneriske o.s.v. udvikling beror på den $\emptyset$ konomiske. Men de virker også tilbage på hinanden og på den $\varnothing$ konomiske basis. Det er ikke sådan, at de økonomiske forhold er årsagen og alene aktive og alt det andet kun passiv virkning. Der består tværtimod en vekselvirkning på grundlag af den $\varnothing$ konomiske nødvendighed, der $i$ sidste instans altid gør sig gældende $\ll{ }^{80} \varnothing$ konomiens determinans i sidste instans fungerer igennem en særlig strukturel - en »metonymisk « - kausalitet, som anviser hver region og niveau sin funktion og rolle, jfr. ovenfor. Den videnskabeligt materialistiske analyse formidles således igennem »struktur«begrebet. $^{81}$

\section{De tre grundproblemer:}

\section{Retten som overbygning.}

Bygningsmetaforen »basis/overbygning « hos Marx er hos Althusser udgangspunktet for teorien om strukturens forskellige niveauer og deres samspil. Jfr. N. Reich:

79. Roepstorff (note 69) p. 79 ff. - Iflg. Poulantzas (note 59) p. $233 \mathrm{ff}$. er det »den juridiskpolitiske region «, der dominerer i den kapitalistiske ideologi, da »den är bäst lämpad för att fylla den särskilda roll som tilkommer ideologien«, nemlig både en isoleringseffekt, konstitueringen af »individet «, og en sammenbindingsrolle, konstitueringen af det »nationale fællesskab «. »När det emellertid mera specifikt gäller statsmonopolkapitalismens stadium, i vilket den dominerande rollen innehas av politikken, är det den ekonomiska ideologien - av vilken »teknokratismen« bara är en aspekt som tenderar att bli den dominerande ideologiens dominerande region «.

80. Brev til Starkenburg MEUS p. 505, jfr. også brev til Bloch MEUS p. $488 \mathrm{ff}$.

81. Jfr. kritik heraf hos Schanz (note 5) p. 20 - 38, især note 8 og 25, og p. $188 \mathrm{ff}$. 
»Når man først har forstået basis og overbygning som strukturelle kendetegn ved enhver historisk samfundsformation, så melder spørgsmålet sig om deres gensidige forhold. $\ll^{82}$

Overbygningen udgøres af de tre niveauer det politisk-juridiske, det ideologiske og det teoretiske. Den metonymiske kausalitet er afgørende for basis' indvirken på overbygningen og omvendt og for de indbyrdes relationer mellem overbygningens forskellige niveauer. Vi har ovenfor set flere eksempler herpå.

Det retlige system etableres som selvstændigt objekt for videnskabelig analyse igennem bestemmelsen som særligt niveau, der er relativt autonomt, hvorved alle simpelt deterministiske, mekanisk kausale (»økonomistiske«) forklaringer på forholdet mellem $\varnothing$ konomi og ret er tilbagevist.

I følge Poulantzas er politikken indehaver af den dominerende rolle under statsmonopolkapitalismen, ${ }^{83}$ og ifølge $N$. Reich »er det også tænkeligt, at retten kan spille den dominerende rolle, f.eks. i det 19. århundredes retsstatslige ideologi eller i forestillingen om en »retliggjort politik« (jfr. Seifert: Verrechtlichte Politik und die Dialektik der marxistischen Rechtstheorie, Kritische Justiz, 1971 p. $185 \mathrm{ff}) \ll .{ }^{84}$

\section{Retten som historisk fænomen.}

I »struktur«-begrebet ligger en dobbelt historicitet: En »ahistorisk historicitet og en »konkret historicitet«.

Med det første mener jeg, at strukturen »produktionsmåde« med dens 4 niveauer (og »basis/overbygnings«-modellen, jfr. N. Reich-citatet ovenfor ved note 82) anvendes ahistorisk som analyseredskab på alle teoretisk rene, men historisk forskellige samfund, nemlig både på den kapitalistiske og på præ-kapitalistiske og socialistiske »produktionsmåder«. Udgangspunktet for denne betragtning er bl.a. Marx' udtalelse om »at enhver form for produktion skaber sine egne retsforhold $\ll .85$

Med det andet mener jeg, at strukturen »samfundsformation« udtrykker et historisk konkret samfund, som består af flere »produktionsmåder«, hvor dog én er dominerende.

I en samfundsformation indgår der altså flere forskellige retlige niveauer, nemlig et fra hver af de produktionsmåder, som udgør samfundsformationen. Det overvejende indhold i samfundsformationens retlige niveau bestemmes af retten i den dominerende produktionsmåde (overdetermination). Retten i samfundsformationen udgøres altså af flere forskellige teoretiske rene »retter «, f.eks. er der både feudale, konkurrencekapitalistiske og statsmonopolkapitalistiske (og socia-

82. N. Reich (note 2) p. 22.

83. Poulantzas (note 59) p. $233 \mathrm{ff}$.

84. N. Reich (note 2) p. 21.

85. Marx »Indledning « til »Grundrids« (note 5) p. 10. 
listiske?) retlige træk i dansk gældende ret, men det er den statsmonopolkapitalistiske, der dominerer.

\section{Retten som klasseret.}

Da teorien forankres hos den »modne « Marx og hans analyse af produktionsforholdene og deres reproduktion i den kapitalistiske »produktionsmåde«, bliver klassebegrebet centralt, da netop den kapitalistiske produktion stadig reprocerer klasseforholdet. Det er ikke det humanistiske »nøgne individ «, (som f.eks. hos den kritiske teori) men mennesker som barere af strukturer, - f.eks. de kapitalistiske produktionsforhold, - der er grundlaget for denne klasseteori. Og på grund af rettens ovenfor angivne strukturelle funktioner fungerer retten i et klassesamfund som klasseret. »Det er denne videnskabelige analyse og ikke en henvisning til Marx' ungdomsværk, som tillader én at se, at den moderne ret er en klasseret ${ }^{86}$

»Det er indlysende, at den moderne ret svarer til klasseudbytningen og det politiske klasseherredømme. Forholdet mellem retten og klasseherredømmet kan dog på ingen måde reduceres til opfattelsen af en klassevilje, der er det skabende subjekt af retten. Den kan heller ikke reduceres til den repressive sanktion, der karakteriserer de juridiske regler, kort sagt til en eller anden utydelig voldens rolle $\mathrm{i}$ historien. Tydningen af det væsentlige forhold mellem retten og klassekampen kan kun foretages videnskabeligt via dens forudgående lokalisering i den komplekse helhed af strukturer i en produktionsmåde og en samfundsformation; det er denne lokalisering, som præcist giver os nøglerne til en undersøgelse af dens forhold til $»$ klassekampens felt $\ll .{ }^{87}$

\section{Materialistisk retsteori. ${ }^{88}$}

Betegnelsen »materialistisk « udtrykker her den specifikt polit- $\varnothing$ konomisk reflekterede »materialistiske udledning « inden for den teoretiske ramme, som den Marxske teori forstået som »kritikken af den politiske $\emptyset$ konomi« sætter.

86. Poulantzas (note 3) p. 101.

87. Poulantzas (note 3) p. $101 \mathrm{f}$.

88. Se til dette afsnits generelle teoretiske problemstilling: H.-J. Schanz, (note 5) med udførlig argumentation og henvisninger.

Specielt om de retsteoretiske problemer: Eckart Osborg, (note 52). Oscar Negt, »Teser til en marxistisk retsteori«, Kurasje nr. 10, 1974, p. 56 ff. T. Wanscher, »Retlig teori og praksis«, Teori og Praksis nr. 1, 1973, p. 72 ff. Samme (note 1) med henvisninger, bl.a. citatbelæg fra E. Osborg.

Til dette afsnit er jeg iøvrigt af praktiske (først og fremmest pladsmæssige) grunde tvunget til hos læseren at forudsætte kendskab til Marx' kapitalanalyse, som den er fremstillet i Kapitalen. 


\section{A. »Kritik af den politiske $\varnothing$ konomi}

»Kritik af den politiske $\varnothing$ konomi« er den fællestitel, som Marx gav sine teoretisk vigtigste skrifter efter $1857 .{ }^{89}$ Opfattelsen af »Den marxske teoris forfald $«{ }^{90}$ og den dermed sammenhængende rekonstruktionsintention overfor denne teori går ud fra tesen om, »at den marxske teoris grundkerne skal findes inden for kritikken af den politiske $\varnothing$ konomi $\ll^{91}$

Denne indeholder analysen af den almene kapitallogik, kapitalbegrebets logiske struktur, og dermed samtidig den kapitallogiske reproduktion, på et teoretiskabstrakt analyseniveau (»kapitalen i almindelighed «). Tesen er den, at netop denne analyse etablerer den teoretisk nødvendige ramme for en videnskabelig erkendelse af samfundstotaliteten, herunder retten, i et kapitalistisk samfund. Det er altså ikke en kun $\varnothing$ konomisk teori, men en teori for det kapitalistiske samfund som en sig reproducerende totalitet.

Og dermed har vi problemet. Hvordan formidles denne kapitallogiske analyse til en analyse af samfundets forskellige genstandsfelter, f.eks. det retlige system? Kan f.eks. den borgerlige ret forklares materialistisk blot ved at forlænge den marxske vareforms-analyse til en analog retsforms-analyse (som hos Paschukanis ${ }^{92}$ )? Med andre ord, hvad er kritikken af den politiske $\varnothing$ konomis omfangslogiske status i relation til analysen af den borgerlige ret?

»At ville oparbejde kritikken af den politiske $\varnothing$ konomis omfangslogiske status implicerer derfor som første led en indsnævring for så vidt som man må finde ud af, hvad kritikken er anvendt i relation til af Marx. Vi har set, at denne indsnævring har to områder, som den kommer til udtryk på: dels gennem en afuniversalisering af den historieteoretiske intention, og dels igennem en påpegning af, at kapitallogikken ikke opsluger alt indenfor det borgerlige samfund som totalitet $\ll .{ }^{93}$

\section{Produktion og ret.}

Problemet består således i en afklaring af forholdet mellem produktion og ret. ${ }^{94}$

Den gennemgående tankegang er den, at den borgerlige rets almene form og umiddelbare indhold er direkte produceret af cirkulationssfarens ækvivalente varebytte, og må nødvendigvis være det.

Men kun den i produktionssfaren eksisterende merværdiproduktion kan danne grundlag for en materialistisk udledning af den borgerlige ret. Dette har

89. »Politisk $\varnothing$ konomi« var den daværende betegnelse, som de borgerlige nationaløk onomer, f.eks. Ricardo og A. Smith, selv anvendte for deres økonomiske teorier, i erkendelse af deres samfundstotaliserende politiske karakter.

90. Schanz, (note 5) p. 7 ff., Osborg (note 52) p. 7 f.

91. Schanz, (note 5) p. 16.

92. Jfr. T. Wanscher (note 1) p. 8 ff.

93. Schanz, (note 5) p. 186.

94. Se hertil de i note 88 anførte forfattere, hvor problemet behandles udførligt, hvorfor sammenhængen blot her skitseres. 
sin forklaring $\mathrm{i}$, at den borgerlige ret (igennem institutterne: den private ejend omsret, den frie kontrakt o.s.v.) er den nфdvendige forudsatning for - og får sin specifikke form igennem - det kapitalistiske (i modsætning til det simple) varebytte, salget af varen arbejdskraft. Og dette varebytte er netop det nødvendige formidlingsled og dermed konstituerende for den kapitalistiske (merværdi-)produktion.

»Da den marxske kritikmetode væsentligt består i påvisningen af de samfundsmæssige fænomeners formidlethed, er dette skridt fra cirkulationen til produktionen (min understregning, T.W.) ikke blot metodisk og sagligt begrundet, men modsvarer også den politiske $\varnothing$ konomis reale udviklingsgang $\ll .{ }^{95}$

\section{Den almene retsform.}

Analysen af rettens form tager således sit udgangspunkt i produktionen, som enhed af arbejds- og valoriseringsproces.

Iflg. Osborg ${ }^{96}$ er »lovens« begreb den mest almene retsform. Den er iflg. sit begreb samfundsmæssig »almen«. Men på grund af den kapitalistiske produktions modsigelsesfulde karakter som valoriseringsproces kan den kapitalistiske almene lov udelukkende antage »ubestemthedens « form, altså antage generalklausulens karakter. De reelle produktionsbetingede samfundsmæssige modsigelser slår nemlig igennem på samfundets overflade som en tilsyneladende enighed, som finder sin form i en parlamentarisk »ubestemt « lov, som altså i realiteten er en generalklausul. Loven transformeres til »bestemt « form i dommen, hvor den samfundsmæssige skinenighed omformes til en samfundsmæssig tvangsenighed.

Iflg. det borgerlige lov-begreb er loven i sig selv både almen og bestemt. Derfor dækker det borgerlige generalklausul-begreb blot et graduelt fortolkningskompetence-fordelingsproblem mellem parlament og domstole. Den borgerlige almene og bestemte lov er således et ideologisk begreb, som har sin reale produktive basis i den simple vareproduktion, i hvilken netop dette lovbegreb kan tænkes modsigelsesfrit.

Se også til problemet om retsformen neden for under punkt 5 om det kapitalistiske samfunds »overflade« som konstitutionsfelt for den borgerlige rets »almenhed «.

\section{Kritik.}

Den materialistiske analyse er altid kritisk, men den materialistiske kritik udspringer af analysens indtrængen i produktionens klassemodsatninger.

Kritikken bliver på samme tid en fremstilling af rettens sammenhæng med kapitalens produktion, reproduktion og udviklingstendenser og et led $i$ overskridelsen af den borgerlige ret igennem sammentænkningen af ret og kapitalismens udvikling

95. O. Negt, (note 88$)$ p. 71.

96. Se T.Wanscher, (note 1) p. $28 \mathrm{ff}$. 
og grænser. Den er altså et led i udviklingen af de videnskabelige forudsatninger for en socialistiske strategi og taktik.

Dens emancipative orientering er proletariatet som klasse (politøkonomisk defineret igennem kritikken af den politiske $\emptyset$ konomi), d.v.s. denne klasses ophævelse ved afskaffelsen af lønarbejdet.

Den materialistiske kritik har således en helt anden orientering end den moralske, humanistisk-antropologiske kritik hos den »kritiske« teori.

\section{Ideologi og ret.}

Den materialistiske analyse af ideologien viser den som en med nфdvendighed fordrejet bevidsthed.

Denne produceres som borgerlig bevidsthed gennem arbejdslonnens form, som skjuler det ubetalte arbejde, idet arbejdslønnen fremtræder som betaling for det præsterede arbejde og ikke for den købte arbejdskraft. ${ }^{97}$ Denne forvandling af »arbejdskraftens værdi« til »prisen på arbejde« udtrykker konstitueringen af arbejdslønnen som revenue i forhold til sin kilde: arbejdet. ${ }^{98}$

På tilsvarende vis udtrykker merværdiens forvandling til profit og dennes spaltning i gevinst og rente konstitueringen af profitten som revenue i forhold til sin kilde: kapitalen. »Som rentebærende pengekapital ... antager kapitalen sin rene fetischform ${ }^{99}$

»Revenuens form og revenuens kilde udtrykker den kapitalistiske produktions forhold i den mest fetischagtige form. Det er dens eksistens, således som den ser ud på overfladen, skilt fra den skjulte sammenhæng og det formidlende mellemled $\ll .{ }^{100}$

Det kapitalistiske samfunds »overflade« betegner således produktionens mest fetischagtige former, hvor ethvert spor af den kapital-logiske merværdiproduktion for den umiddelbare bevidsthed er forsvundet i mystifikationer.

Vare-penge-vare er det kredsløb, som på overfladen både arbejderen (arbejderevenue (løn)-konsum) og kapitalisten (kapital-revenue (profit)-konsum) reproducerer sig igennem. Derved bliver netop cirkulationssfarens kategorier konstituerende for ideologien. Cirkulationssfærens kategorier konstitueres samtidig som retlige gennem den nødvendige sikring af det formelt ækvivalente varebytte (og dermed også merværdiproduktionen) i ejendomsrettens og kontraktens retlige former.

97. Kapitalen MEW 23, p. 562 (Rhodos p. 762), Negt (note 88) p. 74 ff, og T. Wanscher (note 88) p. $75 \mathrm{ff}$.

98. Se til problemet om revenuerne og »overflade«-begrebet: Kapitalen MEW 25, især p. $822 \mathrm{ff}$. (Rhodos p. 1047 ff.), Flatow og Huisken, »Den borgerlige stats afledningsproblem«, Kurasje nr. 9 og 10, 1974, og Ole Marquardt, »Konjunkturforløb og klassebevidsthed «, Den jyske historiker nr. 1, 1974, især p. $12 \mathrm{ff}$. og $45 \mathrm{ff}$.

99. Kapitalen, MEW 25, p. 406 (Rhodos p. 509).

100. Marx i Theorien über den Mehrwert, citeret efter Flatow/Huisken (note 98) p. 147. 
Derfor er de retlige kategorier med nфdvendighed umiddelbart afledt af varebyttet (cirkulationen) og ikke af produktionens logik (arbejds- og valoriseringsproces), og rettens ideologiske aspekter opstår som følge af disse netop nævnte merværdi-skjulende og samtidigt merværdiproduktionformidlende overfladekredsløb.

Ideologien er således udtryk for denne overflade-bevidsthed, d.v.s. revenuebevidsthed. Dens væsentlige indhold er bevidstheden om »de fælles interesser« (socialpartner-bevidsthed), om »lighed « (ønsket om ligeligere indkomster, altså revenuer) og »frihed « (til at udnytte sin revenuekilde, f.eks. arbejdet).

Disse centrale retligt-ideologiske kategorier har både en kun formel og en real gyldighed.

I forhold til produktionens udbytning og klassekonstituering er cirkulationssfærens ækvivalenslogik kun formel. Men på overfladen, - hvor alle fremtræder som (»lige og frie«) privatejere (nemlig af deres revenuekilder), der skaffer sig sit revenue og konsum gennem ækvivalente varebytter og derfor har den »almene interesse « at sikre privatejendommen, - har disse kategorier i deres revenue-formidlede fremtrædelse en real eksistens.

\section{Samfundets overflade og retten.}

Det er således på samfundets overflade, hvor alle væsentlige forhold fremtræder i fordrejet form, at ideologien, herunder den retlige, konstitueres.

Er det også her den retlige form konstitueres? Flatow/Huisken har forsøgt en materialistisk udledning af den borgerlige stats form med udgangspunkt i overfladens konstituering af alle, arbejdere og kapitalister, som revenuemodtagere. Disse fremtræder samtidig som privatejere af deres revenuekilder. »Denne udifferentierede sammenfatning af forbrugsgoder og indkomstkilder finder sin pendant i et tingsliggjort juridisk ejendomsbegreb $\ll^{101}$.

På overfladen konstitueres den »almene interesse«. Alle fremtræder jo her som »privatejere«, hvorfor det er i alles interesse at sikre privatejendommen, d.v.s. at sikre sine revenuekilder, således at alles revenue kan flyde i en fast og uforstyrret strøm. Dette skal staten sikre. Statens funktioner er forvaltningen af de »almene interesser«: Krisebekæmpelse (»sikring af den fulde beskæftigelse«), etablering af lige konkurrencebetingelser (»bekæmpelse af konkurrenceforvridning «), sikring af arbejdskraftens reproduktion (»socialvæsenet«) og kvalifikation (»uddannelsessystemet«) o.s.v. o.s.v. Synspunktet er: Opretholdelsen af »kapital og arbejde som produktionsfaktorer« (d.v.s. revenuekilder).

Dermed konstitueres den borgerlige ret som form, hvorigennem borgernes »almenhed « som privatejere finder udtryk. Statens forvaltning af de almene interesser sker nemlig ved »kodificering som lov, bekendtgørelse, bestemmelse etc., som 
udgør den for alle privatejere bindende form for varetagelse af almene interesser ${ }^{102}$

Retten er således »ikke en statsfunktion, men en for staten særlig resultant af forvaltningen af de almene interesser ${ }^{103}$. Hermed er også rettens funktioner bestemt ud fra den overflade-konstituerede »almene interesse «.

\section{Rettens funktioner som kapitalaffirmative.}

Rettens funktioner kan kun forstås ud fra dens forhold til kapitalens kredsløb. Vi har set dens nære tilknytning til den umiddelbare kapitalcirkulation og -produktion. Først og fremmest i privatrettens form.

Men der er ikke her tale om, at det retlige system er umiddelbart subsumeret under kapitalen. der er tale om et kapitaleksternt samfundsmæssigt system, som dog er $n \phi d v e n d i g t$ for at sikre, at de menneskelige aktiviteter gøres kapitalreproduktionsaffirmative.

\section{Fasespecifikke retsformer.}

De i den kapitalistiske reproduktion indbyggede modsigelser, - krisecyklen, arbejdskraftnedslidningen o.s.v. -, kræver reguleringsmekanismer, som primært organiseres gennem staten. Statsinterventionismens funktionsform er i overvejende grad (ikke udelukkende) det retlige system, her i den offentlige rets form. Kriseregulering, sikring af arbejdskraftens reproduktion og kvalifikation, o.s.v. bliver $\mathrm{i}$ stigende grad dele af rettens funktioner. Dette er forklaringen på, at »retten « hos Marx, - der jo analyserede et laissez-faire liberalistisk samfund, - overvejende er privatretten. Dette er et gennemgående træk hos den post-marxistiske retsteori, der næsten udelukkende har beskæftiget sig med privatretten. F.eks. reducerede Paschukanis begrebet $»$ ret « til privatret. ${ }^{104}$

Denne stigende statsintervention giver sig udslag i en anden retsform end den traditionelle borgerlige almene og (u)bestemte lov. Denne er nemlig udtryk for en formel rationalitet, der skal sikre de formelt frie og lige privatejeres handleevne, altså vareudvekslingen. Derimod udtrykker den statsinterventionistiske retsform en indholdsmassig rationalitet, da retten er funktionsformen for den konkrete formålsbestemte statslige indgriben i det borgerlige samfunds kredsløb. Denne særlige retsform giver sig udslag i helt konkrete foranstaltninger i lovsform (f.eks. Lov nr. 73 af 19/2 1974 om omkostningsdæmpende ydelser til arbejdsgivere), men især i omfattende bemyndigelser til administrationen, navnlig i rammelovens form (f. eks.

102. Flatow/Huisken (note 98) p. 25. Den danske oversættelse er her fejlagtig, da den lyder: »en form for«. Også på side 27 er »Die Rechtsförmigkeit«, oversat til »den retsudformning«. Oversættelsen skal også her være i bestemt form: »den antagen af retsformen«. Endvidere er »Privateigentümer« forkert oversat til »privatbesidder «.

103. Flatow/Huisken (note 98) p. 27.

104. Jfr. T. Wanscher (note 1) p. $8 \mathrm{ff}$. 
Forslag til lov om arbejdsmiljø, fremsat d. 13/6 1974). Med denne forskydning fra parlament til administration sikres den indholdsmæssige rationalitet i indgrebet, som på denne måde lettere løbende kan justeres. Altså en fleksibilitet i interventionen som ikke kan sikres i den traditionelle lovsform. Der er således tale om fasespecifikke retsformer inden for det kapitalistiske samfunds udvikling, således at funktionsområdet for den almene lov i stigende grad formindskes, samtidig med at den konkrete lov og rammeloven udvikler sig som de til statsinterventionen svarende retsformer. ${ }^{105}$

\section{B. Materialistisk udledning.}

Den som »materialistisk udledning « formulerede videnskabsintention tager sit udgangspunkt i det oven for under III B omtalte videnskabsbegreb hos Marx.

Det er endvidere den grundlæggende opfattelse, at »man ikke, efter at kritikken af den politiske $\varnothing$ konomi er gennemført, stadig kan operere med et selvstændigt og lukket materialistisk grundsyn, som står ganske uberørt ved siden af kritikken af den politiske økonomi, ej heller kan man meningsfuldt opfatte kritikken af den politiske $\varnothing$ konomi som blot et tidsmæssigt og objektspecifikt konkret specialstudie inden for rammerne af den logik, som eksplicite skulle være sat med det materialistiske grundsyn, således som dette udtrykkes kategorialt og uproblematisk inden for den postmarxske tradition... «106

Men på trods af det fælles udgangspunkt er - som det vil være fremgået - opfattelsen af den metodiske fremgangsmåde ikke entydig.

Flatow/Huisken kritiserer flere materialistiske teoretikere for »en metodisk utilladelig udbredelse af bestemmelserne af bytteakten eller den simple varecirkulation «107, men på den anden side kritiseres overfladen som udledningsgrundlag: »Så længe man bestemmer statens »særegenhed « og dennes fremtrædelsesmåder alene ud fra en hypostasering og ontologisering af den fordrejede bevidsthed og ikke ud fra de historisk-materialistiske betingelser for produktion og reproduktion, kommer man næppe frem til en »materialistisk « statsudledning. $\ll^{108}$

Den almene kapitallogiks totaliserende intention giver problemer: Kan det kapitallogiske udgangspunkt kun danne basis for almene retsformsanalyser?

105. Se til denne problematik: Thomas Blanke, »Das Dilemma der verfassungspolitischen Diskussion der Linken in der Bundesrepublik« trykt i Hubert Rottleuthner, Hrsg., »Probleme der marxistischen Rechtstheorie«, Frankfurt/M 1975, p. 419 ff, og Thomas Blanke m.fl., »Ansätze materialistischer Verfassungs- und Arbeitsrechtstheorie«, Kritische Justiz, hefte 1 1975, p. $24 \mathrm{ff}$.

106. Schanz (note 5) p. $26 \mathrm{f}$.

107. Flatow/Huisken (note 98) p. 10.

108. Hirsch, »Elemente einer materialistischen Staatstheorie«, p. 234. Trykt i Braunmühl m. fl., »Probleme einer materialistischen Staatstheorie«, Frankfurt/M 1973. 
Nej, men hvordan formidles analysen af de konkrete samfundsfænomener? Hvordan formidles forbindelsen mellem den abstrakte væsens-logiske (kapitallogiske) analyse og de historisk-konkrete empiriske retsfænomener?

Vi har hermed formuleret den marxistiske realanalyses problem for så vidt angår analysen af retlige fænomener. Og ved indløsningen af denne realanalytiske forskningsintention forskydes den marxistiske retsteoris interessefelt overimod konkrete empiriske analyser af specielle retlige problemer inden for særlige retsområder, f.eks. arbejdsret, lejeret, formueret osv., i modsætning til den kritiske teoris idealistiske kritik og den strukturalistiske systembygning, men også i modsætning til de materialistiske abstrakte retsformsanalyser, der udelukkende bevæger sig på analyseniveauet $» k$ kapital i almindelighed «.

Den kapital-logiske analyse kan ikke umiddelbart forklare det historisk specifikke, men fastlægger de begrebsmæssige rammer for analysen af de empiriske samfundsfænomener, også de retlige, da kapitallogikken afdækker samfundshelhedens sammenhængs- og udviklingslogik. Og heri indgår den afgørende samfundsmæssige modsætning mellem klasserne som et centralt element. Denne modsætning antager på samfundets overflade klassekampens form, som den overfladeform, hvorigennem den historiskkonkrete udvikling bevager sig under kapitalismen. Igennem klassekampen formidles de kapitallogiske sammenhænge til den historiske specifitet i al sin empiriske forskellighed. Kapitallogik og klassekamp er således de kategoriale nøgler til realanalytisk forskning af kapitalismen og dens retssystem. ${ }^{109}$

\section{De tre grundproblemer.}

Lad os herefter vende tilbage til de traditionelle tre hovedtemaer.

\section{Retten som overbygning.}

Bygningsmetaforen har ikke nogen selvstændig værdi som kategori i en videnskabelig samfundsanalyse. Den må selv forstå historisk.

Det afgørende indhold i denne basis/overbygning-model hos Marx er opgøret med den på daværende tidspunkt dominerende idealistiske videnskab. Akcenten hos M. lå på understregningen af den materielle produktions betydning (også for forståelsen af retten) i modsætning til »ideen « (Hegel), »folkeånden « (Savigny) eller hvad det nu ellers hed. Denne polemiske brod mod idealismen må med, hvis man vil forstå denne teori.

Endvidere må det fremhæves, at den daværende kapitalistiske stats- og samfundsform med sin liberalistiske politiske ideologi var natvægterstaten og laissezfaire $\varnothing$ konomi. Det karakteristiske ved dette samfund var netop en stærk adskillelse

109. Denne tankegang er nærmere udviklet i Torben Wanscher, »Teori og retshistorie«, Tidsskrift for Rettsvitenskap, nr. 2, 1975. 
mellem stat (overbygning) og samfund (basis), »fordoblingen af samfundet i samfund og stat«, som Marx så ofte fremhæver i ungdomsskrifterne. ${ }^{110}$

Bygningsmetaforen angiver altså hos den unge Marx den materialistiske videnskabsintention, som senere udfoldes i kritikken af den politiske $\phi$ konomi, jfr. ovenfor.

Denne model er således kapitalisme-specifik - og åbenbart fremtrædende i den laissez-faire liberalistiske fase - og har ikke nogen selvstændig analytisk værdi ved siden af kritikken af den politiske økonomi.

Sondringen »dybde« / »overflade« er kategorialt forskellig fra »basis« / »overbygning «, selv om der er overlapninger. Dybden refererer sig til samfundets (mer-)værdiproduktive reproduktion, hvorimod overfladen er denne produktions immanent nødvendigt fremtrædende fordrejede og fetischerede former.

\section{Rettens historiske betingethed.}

Den marxske teori er en teori for det borgerlige samfund, jfr. den ovennævnte »afuniversalisering « af kritikken af den politiske $\varnothing$ konomi.

Det borgerlige samfund er varebyttets samfund, den borgerlige ret er det varebyttende samfunds ret.

Det kapitalistiske samfund repræsenterer den mest udviklede form for det varebyttende samfund, og den kapitalistiske ret får dermed sin historiske specifitet som det varebyttende (borgerlige) samfunds ret i sin mest udviklede form.

En materialistisk retsteori er derfor en teori for den borgerlige ret.

Dette udgangspuntk ligger bag de tidl. nævnte »retsforms«-analyser, f.eks. hos Negt, hvor retsformen knyttes til værdilovens eksistens. ${ }^{111}$

Dermed får teoretisk (altså i materialistisk betydning) funderede analyser af »retten «, den historiske karakter, at stille spørgsmål om det kapitalistiske samfunds begrebslige konstituenter, deres logisk-historiske genese og udviklingstendenser (hvilket er indholdet i den marxske kritik af den politiske $\emptyset$ konomi). Analysen er begrebsligt koncentreret om udviklingen af det varebyttende (borgerlige) samfunds ret. Også selv om varebyttet kun fungerer som enklave i et ikke-varebyttende samfund. Dette samfund inddrages kun i analysen som forståelsesramme og illustration. ${ }^{112}$

\section{Retten som klasseret.}

»Den, der taler om klassejustits, må først og fremmest tale om produktionen «. ${ }^{113}$

Bestemmelsen af den kapitalistiske ret som »klasseret « foretages ud fra dens funktioner i det kapitalistiske samfund, hvis produktion foregår på grundlag af be-

110. F.eks. i kritikken af Hegels statsret, jvf. MEW 1, p. 203

111. Negt (note 88) p. 62.

112. Se hertil Torben Wanscher (note 109).

113. Negt (note 88) p. 74. 
folkningens deling i klasser og som stadigt reproducerer denne klassedeling. Med andre ord, det er rettens funktioner i kapitalens reproduktion, der er afgørende for rettens karakter af klasseret.

Det er ikke rettens medvirken til en »uretfardig fordeling af forbrugsgoderne « men dens funktioner i relation til den kapitalistiske produktionsmådes stadige reproduktion af samfundet som et klassesamfund. Først denne teoretiske lokalisering af rettens funktioner kan danne grundlag for en proletarisk revolutionær strategi, der omfatter den borgerlige ret som både kampobjekt og -medium.

Det er »overhovedet ... fejlagtigt at gøre så meget væsen ud af den såkaldte fordeling og lægge hovedvægten på den.

Den til enhver tid eksisterende fordeling af forbrugsmidlerne er kun en følge af fordelingen af selve produktionsbetingelserne. Men denne fordeling er karakteristisk for selve produktionsmåden. Den kapitalistiske produktionsmåde f.eks. hviler på, at de materielle produktionsbetingelser er tildelt ikke-arbejdere i form af kapitalejend om og grundejendom, mens massen kun er ejer af den personlige produktionsbetingelse: arbejdskraften. Når produktionens elementer er fordelt på en sådan måde, så følger den nuværende fordeling af forbrugsmidlerne af sig selv ... Vulgærsocialismen (og fra den atter en del af demokratiet) har fra de borgerlige $\varnothing$ konomer overtaget den vane at betragte og behandle fordelingen som uafhængig af produktionsmåden, og følgelig at fremstille socialismen som en lære, der i hovedsagen drejer sig om fordelingen. Hvorfor skal vi igen gå baglæns, efter at det virkelige forhold forlængst er klarlagt? «114

\section{Konkret analyse. Det arbejdsretlige system.}

På marxistisk retsteoretisk grundlag er der i de senere år kommet enkelte analyser af konkret retsstof. Disse har navnlig vedrørt det arbejdsretlige system. ${ }^{115}$ Dette er teoretisk stringent, da netop dette retsområde regulerer det varebytte, som ifølge den marxske teori er konstituerende for kapitalismen, nemlig salget af arbejdskraft.

Generelt kan det siges, at analyserne overvejende indskriver sig i den kritiske teoris forskningslogisk-reduktive (ideologikritiske) tradition. Analysernes hovedindhold er påvisningen af det arbejdsretlige systems klassekarakter, da det skal regulere klassekampen på kapitalens præmisser, og arbejdsdomstolenes karakter af

114. Marx i »Kritik af Gothaprogrammet«, MEUS II p. 18.

115. Thomas Blanke, »Funktionswandel des Streiks im Spätkapitalismus«, Frankfurt/M 1972. Per Eklund (note 57), Sten Edlund og Per Eklund, »Rätt och arbetsgivarmakt«, Stockholm 1974. Gösta Hultén, »Arbetsrätt och klassherravälde«, Stockholm 1971. Ulrich Mückenberger, »Arbeitsrecht und Klassenkampf«, Frankfurt/M 1974. Studenterfronten, »Rapport om arbejdsretten«, Århus 1972. Lutz Unterseher, »Arbeitsvertrag und innerbetriebliche Herrschaft«, Frankfurt/M 1969. Endvidere en lang række artikler i Kritische Justiz. 
klassedomstole, da de skal gennemtvinge denne regulering. Der tages samfundsvidenskabelige metoder i brug, som ikke hører til i den traditionelle borgerlige retsdogmatik: f.eks. unders øgelser af dommerideologi, klasse økonomiske konsekvenser, parlamentariske unders $\varnothing$ gelser o.s.v.

»Rapport om Arbejdsretten « adskiller sig fra de andre undersøgelser ved at være skrevet sammen med revolutionært-socialistisk aktive folk fra arbejderbevægelsen i en lokal studenterpolitisk tradition (»ekstern fagkritik«) og er således led i en udvikling af en marxistisk videnskab, som eksplicit orienterer sig mod en politisk praksis i arbejderklassens interesse uden for politiske partier, og uden for etablerede forskningsmiljøer.

»Rätten i Klassekampen « orienterer sig udelukkende imod interessekampen i parlamentet. Dens »klassekamp« foregår i parlamentets udvalg og korridorer. Udgangspunktet er et reformistisk interesse-synspunkt.

Derimod er »Arbeitsrecht und Klassenkampf« orienteret imod analysen af det borgerlige formelle begreb »gældende ret «. Mückenberger vil analysere den engelske »Industrial Relations Act « fra 1971 i dens rent faktiske klassekampseffekter. ${ }^{116}$ Han kritiserer den opfattelse, »at retten er identisk med det, som parlamentet har vedtaget $\ll .{ }^{117}$ Rettens genese og gyldighed kan ikke forstås igennem et formelt retsbegreb, men kun igennem dens forhold til den historisk-konkrete klassekamp.

Denne tese illustreres ved at vise, at den kapitalreproduktive interesse bag loven i virkeligheden var at bane vejen for gennemtrumfningen af en indkomstpolitik, som skulle lette kapitalens akkumulationsvanskeligheder.

Loven skulle til dette formål svække arbejderklassens forhandlingsposition og kampkraft gennem 1) retliggørelse (afpolitisering) af forholdet mellem lønarbejde og kapital, 2) afsvækkelse af arbejdskampene til ren lønkamp, 3) svækkelse af basismilitansen ved at indsætte fagforeningerne som ordensfaktor, og 4) svækkelse af fagforeningerne selv gennem statslig kontrol med fagforeningerne og deres aktionsspillerum. ${ }^{118}$

Men denne funktion fik loven ikke på grund af de voldsomme klassekampe, som den udløste, og Heath-regeringen forsøgte så derefter at gennemtvinge et lønstop.

Hans tese er den, at disse klassekampe og deres virkninger i forhold til de kapitalinteresser, som loven skulle fremme, må medanalyseres for en forståelse af lovens gyldighed. Den står stadig i lovbogen, men i hvilket omfang har den bidraget til gennemførelse af indkomstpolitik?

Denne forbindelse mellem arbejdsmarkedslov og indkomstpolitik kan ikke begribes med et formelt rets-begreb, men kun gennem et materialistiskpolitisk (kapitalinteresse-klassekamp) retligt gyldighedsbegreb. ${ }^{119}$

116. Denne lovgivnings klassekampsproblematik behandles også af Herman Knudsen og Jette Sandahl, »Arbejdskamp i Storbritannien«, Århus 1974. p. 82 ff.

117. Mückenberger (note 115) p. 12.

118. Mückenberger (note 115) p. 11.

119. Se hertil det ovenfor anførte om kapitallogik og klassekamp som de kategoriale nøgler til realanalytisk (rets)forskning. - Om den konsekvent materialistiske analyse hos T. Blanke, (note 115), se T. Wanscher (note 1) p. 32. 